\title{
SOCIAL CONFLICT RESOLUTION \\ THROUGH EMPOWERMENT OF LOCAL WISDOMS
}

\author{
Mohammad Jamin ${ }^{1}$ \\ ${ }^{1}$ Faculty of Law, Universitas Sebelas Maret \\ Email: mohjamin@staff.uns.ac.id
}

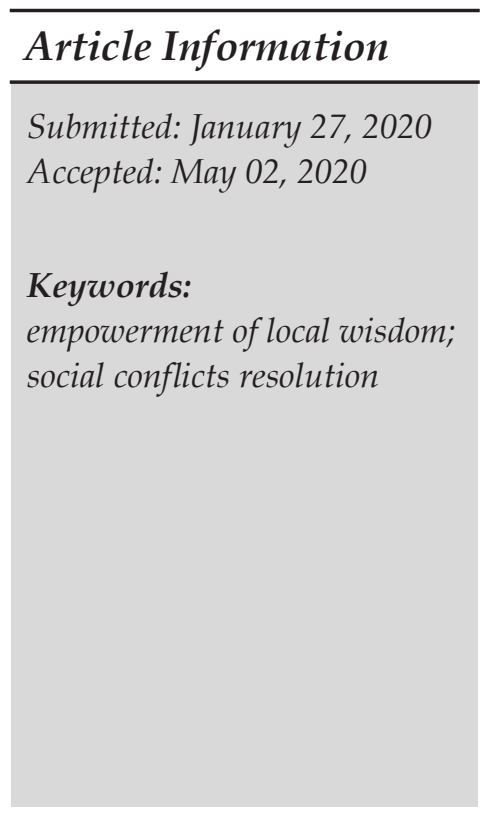

\begin{abstract}
Ethnic, religious, race, and cultural diversity, as well as a large number of populations, are a treasure and strength for the Indonesian people, but on the other hand, it can be potential social conflicts that jeopardize the national integrity. Local wisdom which lived generations by generations and owned by the various local community is a social asset that can be empowered in social conflict resolution. Local wisdom plays an important role, not only preventing social conflict but also providing breakthroughs to resolve conflicts that occurred. Law Number 7 of 2012 On Social Conflicts Resolution which reflects the principles of local wisdom, it should be more empower those principles into reality. This empowerment can be done by actualizing the values and institutionalize of local wisdom in social conflict resolution that is implemented at the stages of conflict prevention, termination of the conflict, and restoration of post-conflict.
\end{abstract}

\section{Introduction}

Society and conflict are an inextricable phenomenon and a necessity that cannot be avoided as long as there has an interaction between people. Indeed, conflict is a normal case; even in some aspects of the conflict has a positive side for the development of society. From an anthropological perspective, conflict is a social phenomenon that cannot be separated from the culture of society, especially in a multicultural society. It can be stressed that conflict is something that cannot be avoided in life together (James P. Spradley and David W. McCurdy, 1987: 11). Conflicts have various forms, for example, conflicts between individuals, between groups, between ethnic groups, between organizations, and various other social conflicts.

The Indonesian nation deals with serious threats related to the potential conflicts in society at any time, both vertical and horizontal. Not surprisingly, the mass media often report conflicts at all levels and places. Social conflicts that occur can jeopardize national integration, which is still and will continue to be a predicament that threatens the Indonesian nation existence at any time for quite a long time in the future, even though the variety and patterns are not always the same (Nasikun, 1995: 4 -5). Various social conflicts are caused by complex factors that cannot be separated from the government system, economic inequality, shifting of social values, the transition of democracy from the previous era which was militaristic, centralistic, dominative, and hegemonic (Karrie McLaughlin and Ari Perdana, 2010: 3). 
A pluralistic nation that could be used for the development of democracy is often drowned by the ideology of pseudo-paced social harmony which is uniformity and centralized. Pluralism can be considered as potential by political approval. Pluralism is considered a potential that can be agreed upon by politics. With all the forces that exist in the country, they do not hesitate to use coercive and representative methods so that the people agree on the political form of government which is completely single and uniform. The State's treatment therefore respected and then internalized by the community into their socio-political awareness. In the freedom of awareness that is biased, the state directs the attitudes and social behavior towards things that encourage discrimination, violence, and dehumanization.

The presence of the reformation era and democracy has provided wider space for the articulation of people's opinions and interests. The problem is, the articulation of opinions and interests is still not free from awareness of the state bias that implies dehumanization. That is why then various forms of human tragedy that emerge are very heartbreaking as we have witnessed in Aceh, Ambon, Sambas, Sampit, Papua, and several other regions. Social conflicts are accompanied by inhumane actions and lead to uncivilized actions occurring in several places. Violence and anarchism seemed to have become a solution to solve every problem at hand.

In a variety of violence that takes place, it often raises the presumption of the powerful invisible hand that also plays a role in creating conflict and human tragedy. The journey of reform that has lasted more than two decades should be able to dismantle the structural and cultural aspects which both influence the people's lives and potentially become conflict drivers. Therefore, conflict management cannot only rely solely on structural aspects and based on the existing power system, but must also reorient the discourse and construction of community thought by empowering local wisdom.

The escalation of social conflict becomes an irony with the fact that people in the archipelago have a lot of local wisdom that leads to a social life that is full of harmony, obedience, kinship, and the value of unity amid differences known as the slogan Bhineka Tunggal Ika, as mentioned in Article 36A of The Indonesian Constitution 1945. In line with the thinking above and the phenomenon of the existence of local wisdom that lives in the community, it is very urgent for examining the empowerment of local wisdom to resolve social conflict.

\section{Research Methods}

This article is based on secondary data research i.e. data consisting of legal texts, literature, and pre-existing research documents (Soekanto \& Mamudji, 2003:1314). Besides, this article uses a legal approach in which legislation or regulations are interpreted under the context of purpose and legal norms (Barak, 2005; Ibrahim, 2005:61). Therefore, this approach suggests a conceptual investigation of the legislation from which the objective element (procedures) and subjective (legal intent) can be identified (Barak, 2005:88).

\footnotetext{
$2 \quad$ Yustisia Volume 9 Number 1 (January-April 2020)

Social Conflict Resolution through ...
} 


\section{Research Result and Discussion}

\section{A. Disentangling the Roots of Social Conflict}

From the perspective of legal anthropology, the phenomenon of conflict arises because of conflicts of values, conflicts of norms, and/or conflicts of interest between ethnic communities, tribes, religions, and groups in society. Besides, conflicts that occur also result from discrimination of regulations and treatment of the government (central) to the community (regional) by ignoring, eliminating, and weakening the values and norms of customary law, including religion and community traditions through domination and hegemony of the state law (I Nyoman Nurjaya, 2005: 95).

Former Vice President Muhammad Jusuf Kalla in his scientific speech after receiving the 2018 UNS Award "Parasamya Anugraha Dharma Krida Baraya", (12/3/2018) stated that the main root of social conflict is the essence of political injustice, economic injustice, social injustice and another form of injustice (https://www.wartaekonomi.co.id/read173350/jk-ketidakadilansumber-utama-konflik.html, accessed on 7 January 2020). Even though many foreign countries have praised the advanced of Indonesian democracy, this does not mean without sacrifice. Political stuttering along with ambitions to control are the dominant contributors to the growing conflict. Meanwhile, the level of economic inequality among regions, regions with the center, between ethnicities (migrants and settlers), between classes and so on, where all of them has potential to trigger conflicts.

Social inequality occurs due to moral degradation, we all see the rise of the "tradition" of corruption, opportunist behavior (aji mumpung) and similar forms like that, have been carried out by several officials and businessmen who are getting worse. Corruption which is detrimental to the people continues to be carried out by white-collar criminal offenders. Strengthening this condition, political power with various forms has become a role model for many in all institutions and organizations. Together with the authority which wrapped-in the various negative labels, they play dirty games that harm the people and make profits for themselves. In the end, the degradation of social morality has become serious illness in the community.

Ipso facto this country is undergoing changes and shifts from the gemeinschaft (long-term community relationship) to the gesselschaft (short-term community relationship). The question is, why is the process of change cited by uncertain directions, disorder, anomie, even indications of chaos? No one can give a single-comprehensive-satisfying answer to that question. Perhaps, a few can give a clue by understanding the so-called great disruption (Fukuyama, 2002) or major chaos in the social order, could be even greater in the future amid ongoing technological progress, social changes, and shifting of the value, among others, First, the economy has jumped from rational capitalism to libidinal capitalism, then has led to the production of hyper-rational production and consumption systems, amid the change of money from the medium of exchange 
into commodities. According to David Bennett's under these conditions, the engine of capitalism works by producing and constructing "cultural images". Example: credit cardholders are enticed by the image of having "freedom" of shopping. Such construction far exceeds the production of the material world itself in the form of "goods" needs. Finally, it further shows the inner expansion and penetration of a cultural logic of late capitalism on human civilization (David Bennet's, 2017: 479-481). Libidinal capitalism (Lyotard, J.F., 2009: 11) is an economy in which actors fulfill unlimited needs amid limited resources, no longer based entirely on rational expectations but have been more influenced by the engine, both in production and consumption. This leap of capitalism is mutually supporting the change in the existence of money, from the function as a medium of exchange to the function as an exchangeable commodity itself.

Second, technology has evolved from atomic physics base to the quantum physics base(Amien, M.A., 2005: 52), in such a way that the digitization of television, telephone, and computer facilitates human life for the process of communication and information display with high speed and unlimited boundaries. Facts and fiction, news and gossip, real reality, and virtual reality, present alternately as a spectacle, making objects witnessed at the same time throughout the universe, making consumers presented in a full day's spectacle. Phantasmagoria of information (Darmawan Salman, 2016: http://alwyrachman. blogspot.com/2011/04/dapatkah-kearifan-lokal-fungsional.html) has taken place, when humans receive several impressions in rapid turnover, such that before they digest, think and reflect on the meaning of that information, the next information has come, changed and rotated again. Humans are immersed in the ecstasy of communication, being at the peak of pleasure from channeling the desire to communicate, but superficial in the substance and meaning of the communication message itself. The third is patria, namely land, and water where humans live their lives, and patriotism as the meaning of Patria's love, has experienced a number of pulls behind the economic leap, communicationinformation. The upward pull embodies regionalism-globalism, when the patria's identity is eroded by regional-global identity which penetrates the boundaries of the existence of nation-states. Davide Cadeddu stated that globalization plunged the role of the state into crisis in connecting individuals and groups of individuals. Nationalism is related to the search for identity, and globalization has reduced national identity so that it has become increasingly thin (Davide Cadeddu, 2019). On the other hand, nationalism experiences a downward pull towards localism-ethnicism, when the patria's identity is romanticized by the identity of ethnic-locality which encloses the boundaries of the existence of indigenity.

Leaps and pulls have embodied the complexity of the order that claims to be an advanced and modern civilization. In such an arrangement, values, traditions, proverbs, sasanti, advice, and slogans that exist in local communities, including eastern culture as a symbol of local wisdom are often given the stigma of decline, primitive, traditional, ancient, rustic, and so on. Then the state considers itself 
to represent the concept of progress and must act as a physician who heals a society suffering from anti-progress disease (Bernadus Steni, 2009: 234).

Conflict which is accompanied by violence and anarchist mass rampage is the practice of resolving different interests that degrade a civilization. Although conflict and competition are elements of social processes that are necessarily present in social interactions as a necessity of cooperation and peace, violent conflict must be seen as a deviation from the order of civilization. Theoretically it does show a number of conflict functions for the social order, but when latent conflict manifests not only as a purposeful conflict but as a violent conflict, it is a social process that does not merely disintegrate the social order at the level of structure and degradation of civilization but brings misery at the level of the individual and humanity.

The globalization effect on increasing inequality, divergence, and social exclusivity is a determinant of weakening social cohesion and, in turn, determines violent conflicts between ethnicities, between groups, between social classes and between regions (Colletta, N.J. and M.L. Cullen, 2000: 23). Inequality, imbalance, and social exclusivity have saved the seeds of tension in such a way that social cohesion cannot overcome ethnic, class, social class, and sub-region divides that are only slightly ignited by violent conflicts which immediately manifest and have large escalations.

The implementation of decentralization and regional autonomy has conditioned a shifting in the structure of power due to democratization in the center as well as in the regions, accompanied by a democratic process in the form of regional elections that have worsened the degradation of social cohesion and became a trigger for conflict so that social ties cannot transcend ethnic, class, social class, and subregional boundaries. As a result, within two decades the social order in several places was marked by social conflict accompanied by violence and acts of anarchism at the regional and local levels that could endanger the integrity as a multi-cultural nation. the study by LIPI concluded that the direction of the regional election had a significant impact and triggered the emergence of conflict accompanied by violence, anarchism, and even degraded humanitarian values (Moch. Nurhasim et.al., 2016: 111). Recent research from the LIPI also concluded that in the development of social conflict due to general elections and regional elections also due to the emergence of conflict in the cyber realm which was considered to have a significant role in the stability of domestic security (Chastiti Mediafira Wulolo and Semuel Renmaur, 2019: 167).

\section{B. The Strengths of Local Wisdom in Social Conflict Resolution}

Local wisdom is a way of life and knowledge as well as a variety of life strategies in the form of activities carried out by local communities in answering various problems to fulfill their needs. In foreign languages, it is often also conceptualized as "local wisdom" or "local knowledge" or "local genius (www. kemsos.go.id, accessed 27/2/2019). Experience-based knowledge comes from the results of living a long time, the substance of which is incarnated in the form 
of important lessons from experience, in the form of points of wisdom, which are then commonly referred to as local wisdom.

Local wisdom certainly does not emerge immediately, but it has a long process so that eventually it is proven, it contains goodness for their lives. His honesty on this side makes local wisdom an inheriting culture, strongly attached to people's lives. That is, to some extent there are perennial values that are firmly rooted in every aspect of this cultural locality (Nurma Ali Ridwan, 2007: 27).

Local wisdom can manifest as 'substance of speech' as well as 'practice of life'. As the substance of the speech, local wisdom is manifested as a statement of wisdom in the form of songs, proverbs, sasanti, advice, motto and messages presented in a prosaic or poetic manner. As a practice of life, local wisdom incarnates in the form of life-filled wisdom as a result of the prescription of the substance of the song, proverbs, sasanti, advice, motto and prosaic and poetic messages. The quality of civilization will be more highly contributed by local wisdom which incarnates not only as words but also as practices of life. The embodiment of local wisdom is limited to the substance of speech mainly related to denotative and connotative speech; while the embodiment of local wisdom as a practice of life is mainly related to prescriptive and transformative speech; but prescriptive and transformative speech puts denotative and connotative speech as preconditions.

Phrases such as menang tanpa ngasorake, ana rembug di rembug, rukun agawe santoso, Siro Yo Ingsun-Ingsun Yo Siro, or ngalah dhuwur wekasane and other phrases words find the context of its manifestations in limited localization namely in Central Java and East Java. Likewise, local expressions that promote harmony, peace, and brotherhood like segilik-seguluk salunglung sabayantaka, paras paros sarpanaya, menyama braya in Bali (Bali Pos, Senin, 06 Oktober 2011). If expressions of the value of local wisdom from the language of the entire archipelago are translated into Indonesian language, or expressions from the language of the whole world are translated into English, the substance of that expression will lose the support of the specific social environment where the local wisdom values are interpreted as life practices.

The power of local wisdom, to be patented in the practice of life, lies in the spirit of language and the boundaries of the social environment, where local wisdom exists. That is what is called language-kindness as well-languagekindness. One understanding and meaning can be expressed in various languages because each language can express any understanding and meaning; but the style and nuance of the pronunciation of the arrangement of letters stringing words and words composing sentences, undoubtedly differ between languages, and by that reason, the power of dissent also differs between the social spheres in which it exists. Therefore, local wisdom is ideally investigated in games of language in the context of localizing their social environment. The problem is, in the era of the complexity of change and information phantasmagoria, the value of wisdom originates from the wisdom of life experience in the womb of local culture; mingled with various other values from the womb of other cultures, it 
only becomes one of various considerations that are internalized and objectified in the individual. Thus, the actor's tolerance for the prescription of his structure is not only based on knowledge from the context of the local structure in which he lives; but also influenced by the knowledge of its global superstructure, making it not always practice living in harmony with the values of the wisdom of its locality. When globalization is based more on scientific knowledge, where scientific knowledge relies on empirical observation, the truth that it generates is not always with good, because empirical reality is not always about good. This makes global speech not always good speech, even though it may be true speech. In contrast to local wisdom, it separates knowledge of reality about good from knowledge of reality about bad, elevating it to become a wisdom lesson, so it is a value of goodness. That is, today we live in games of language that are more filled with a right speech than a good speech.

In the context of modern conflict resolution, it usually uses universal approaches and theories from abroad, so that it does not result in the emergence of a sustainable resolution, eventually, the conflict becomes an iteration that does not provide positive change for the community. Conflict resolution should be adjusted to the context and background or the setting where the conflict occurs, in this case, a universal approach is irrelevant to be applied to deal with conflict problems. There is another form of conflict resolution approach that is often forgotten, namely local wisdom.

Nowadays local wisdom is becoming a general tendency of Indonesian people who have accepted regional autonomy as the best political choice. Evoke regional values for the sake of development becomes very meaningful for the regional struggle to achieve the best performance. During this time, local wisdom lies with the development interests that are centralistic and top-down. Therefore, it is time to explore more local wisdom as a tool or way to encourage regional development under the regional carrying capacity in solving regional problems with dignity (Nurma Ali Ridwan, 2007: 28). The Indonesian people already have one way of resolving conflicts, namely with local wisdom. Conflict resolution with local wisdom can be introduced by developing local wisdomoriented insights. Aside from being useful as an alternative to conflict resolution, local wisdom also maintains and holds fast to national identity.

Multidimensional conflicts that often arise in Indonesia are an accumulation of community disappointment in the implementation of policies that are considered not to have placed their rights and obligations properly. Its application is not easy because many factors are difficult to predict, especially regarding values, culture, geographical conditions, and the developing local context. It can be said that conflict is friction that occurs between two or more camps caused by differences in values, status, power, scarcity of resources and uneven distribution, which ultimately leads to gaps in various fields of life.

Conflict in human life is impossible to separate. Because to fulfill life necessities, humans are generally carried out various businesses which in their implementation are always faced with several rights and obligations. If the 
placement of rights and obligations is done well, then there is little possibility of conflict and vice versa. Related to this, of course, every region in Indonesia does have considerable potential for conflict. Local wisdom is considered as one alternative to solving problems in conflict resolution. Local policies that are rooted and are considered sacred, causing their implementation to be more efficient and effective because they are easily accepted by the community. Local wisdom has the potential to encourage people's desires to live in harmony and peace. Local traditions and culture generally teach peace in harmony with their social environment. This is consistent with the opinion of I Ketut Gobyah, that local wisdom is inherited from generation to generation. It contains norms that teach harmony and togetherness in social life (https://www.seputarpengetahuan. co.id/2017/10/ pengertian-kearifan-lokal-menurut-para-ahli-ciri-ciri-ruanglingkup-contoh.html, accessed on 26/2/2020).

Indeed, the local wisdom approach cannot be compared between one region and another. However, local wisdom is still centered on a cultural approach, by utilizing local values and culture that are already owned by local communities. Local wisdom is integrated with a system of norms, beliefs, togetherness, justice which is expressed as a community tradition as a result of its abstraction and interaction with nature and the surrounding environment over a long period (Deny Hidayati, 2016: 40). Local wisdom is the most effective medium to find solutions in conflict resolution. This condition is carried out by inviting people involved in the conflict to discuss and negotiate their desires with other parties. This will give effect to the form of settlement that is considered possible and appropriate and can be used as an early warning system conflict. The application of local wisdom is not easy, because there are so many external values that are currently adopted by many Indonesians. However, opportunities to prioritize local wisdom as a conflict resolution also still exist. This is under the opinion of Moendardjito who was quoted (Ayatrohaedi, 1986: 40-44) stating that the element of regional culture as a potential local wisdom because it has proven its ability to survive until now.

\section{The Role of Local Wisdom as Prevention and Resolution of Social Conflict}

Local wisdom, as the magical power of experience-based knowledge of a community, has the potential to contribute to solutions to violent conflict and violent actions. The problem then is, in terms of how can local wisdom be useful for resolving social conflicts and violent phenomena? There are at least three dimensions of utilization or revitalization (Ade Saptomo, 2010: 45) local wisdom in conflict resolution. First, the utilization of local wisdom as cultivators of good for individuals (actors). If the wisdom which is the content of local wisdom can instill goodness in the citizens of their social environment; while suppressing emotions, lusts and self-wrath to be tolerant of offending, defeating, hurtful and humiliating actions from others is the good heart; then the impetus for violent conflict and acts of violence can be alleviated through the appreciation and practice of denotative, connotative, prescriptive and transformative remarks 
from local wisdom. In history, human civilization was contributed by custodians of knowledge, from the library of Alexandria (in Egypt) to the virtual world of the internet today (McNeely, I.F. and L. Wolverton, 2010: 46).

Supposedly, advice items from local wisdom were raised as social discourse, providing media and facilitation for each locality to develop their local wisdom, so that our patria became a garden for local wisdom flowers intertwined with one another. Television shows, newspapers, radio broadcasts, opera stories, song lyrics, character interviews, Facebook messages; NGO facilitation, volunteer assistance, corporate social responsibility applications; advice from parents, lecturers and professors, student activities, local school content, discussions installs to cafes; speeches of political figures, directives of regional head candidates to their supporters, rest of legislative members, the behavior of CSOs; and the government's development programs and activities; should become the nursery of local wisdom.

Second, the use of local wisdom as a basis for social capital to uphold social cohesion. Local wisdom is the source of norms, it is a social institution that is obedient to it because of willingness. It is part of an element that informally makes members of the order can coordinate themselves to achieve shared goals, and therefore he is part of social capital (Field, J., 2010:76). When the shared goals are agreed at the local level, it reinforces social cohesion at the local level; if the common goals are compatible with each other between locales, then it reinforces cross-local social cohesion; if the shared goal is in harmony between the local and supra-local levels, then it reinforces vertical social cohesion (Fukuyama, 2002).

Strong social cohesion has a high tolerance for the sensitivity of inequality, imbalance, exclusivity and exploitation as fields for violent conflict and violent action. Therefore, local wisdom should be placed as social capital with the same urgency as natural resource capital, intelligence capital and human resource competencies, physical capital facilities / infrastructure, technological and financial capital, within the governance structure. Behind the prescription of local wisdom informally; multistakeholder contact, government, civil society, the private world, various groups and layers of society within the local order, horizontal cross the local order and vertical cross the local order; it becomes necessary to be facilitated regularly. The facilitation should condition authentic dialogue between parties, in the exchange of knowledge and intersections of different institutional settings; in order to encourage reciprocal relations of discourse on shared issues, the production and reproduction of mutual trust, and the development of multistakeholder networks. Thought and efforts to strengthen social cohesion in order to have high tolerance to prevent and reduce the latent potential of conflict into violent conflict, must continue to be the priority of all parties as illustrated below.

Grebeg Sudiro is an actual example of creative local wisdom developed by the communities around the Pasar Gede Solo to build social cohesion and harmony to prevent conflicts between Chinese descent and natives people 
facilitated by the Regional Government of Surakarta. This local wisdom was built after the 1998 mass riots which were the background of ethnic Chinese conflict with the natives so that it became a very effective medium to prevent the recurrence of the same conflict. Through the motto "Sudiro Kampung Kebhinekaan, Bersatu dalam Keberagaman", Surakarta residents enliven the performance of welcoming the Chinese New Year celebration every year with Grebeg Sudiro. This event always gets a very lively welcome from the people of Surakarta. Grebeg Sudiro is a party, not only a celebration party to welcome the coming of the Sincia New Year, but also a celebration of the beauty of diversity and tolerance. Even though Sincia or Chinese New Year is identical with citizens of Chinese descent, in this celebration all people merge into one regardless of their racial and hereditary background. Besides being enlivened by two different ethnicities, there were two kinds of costumes worn by the committee and participants, clothes with Chinese motifs and Javanese-style clothing.

Meanwhile, in the Minahasa community in North Sulawesi social cohesion is built with the conception of "si tou timou tumou tou" which means that a human being becomes a human in his role of reviving another human being. This conception is interpreted as suggesting that a person's role (tou) is to be a human being, humans are being not given, and have the potential to develop (timou), but he is responsible for reviving (tumou) other humans. Humans must be able to develop their potential or quality to be able to have meaning or role in society. This is the root of the motivation forward of the Minasaha (Koentjaraningrat, 1993: 78).

On the other hand, the utilization of local wisdom to conduct conflict resolution can be done through the development of models of local wisdom practices in conflict resolution and violence that have historically been practiced in people's lives. Considering that most of the local order living in the archipelago has also developed a very effective technical practice of conflict resolution based on local wisdom (Ade Saptomo, 2010: 45). Some of these practices are as illustrated in the following places.

In the Village of Terawas, Musirawas, South Sumatra, there is a tradition of "punjung mentah". If there is a conflict between residents, the guilty party is facilitated to bring "punjung mentah" to the victim's family, in which it contains coffee, sugar, rice, chicken and cigarettes. Tradition of "punjung mentah" is a symbol of remorse and apology to the victim's family. If the "punjung mentah" has been brought, usually the victim's family feels satisfied, respected, accepts it, and holds back its revenge. After giving "punjung mentah", followed by the tradition of fresh flour, people who fight each other and then rub each other on their bodies, they are considered brothers. This way of restraining individual conflicts becomes group conflicts and even communal conflicts (Abdur Rozaki, 2010: 10). In Soe Regency, East Nusa Tenggara, there is a tradition of "okomama", which is a box of various sizes on which the outside is wrapped and coated with traditional woven cloth and inside is filled with betel nut and lime. If there is a conflict or dispute in the community, the warring parties put both hands in 
the "okomama" while pledging and vowing to no longer be enemies and then maintain peace. With that, peace between the warring parties is facilitated, revenge is muted, group conflicts, and even communal are avoided (Abdur Rozaki, 2010: 11). The tradition in the Province of Bali in arranging, repairing, and minimizing conflicts in Pakraman Village is to prioritize conflict resolution through negotiations between those who disagree peacefully and with family. If the conflict cannot be resolved through negotiations between them, then the mediation pattern is adopted, namely the dispute resolution mediated by the Pakraman Village Assembly as a form of peace institution.

The peaceful of conflicts resolution is very important to be put forward to maintain social harmony in the life of the Balinese, and not to cause inner wounds that leave a prolonged grudge. This peaceful and familial settlement, in essence, is an apology from the offender to the injured party and the injured party is willing to accept the apology and is also willing to forgive the offender. The Balinese have more confidence in the decisions of their traditional justice institutions. There is a sense of justice that is actually reflected in each of the traditional legal decisions (Koran TOKOH - Monday, December 20, 2010). The tradition in Bengkulu, in the Selupu Lebong clan, is known for the court involving customary protectors, kutai leaders, and tribal / clan leaders. In Takalar, South Sulawesi is known by Imam Desa who more or less performs the same function as a mediator in social conflict at the local level (Jawahir Tontowi, 2007: 72). In the indigenous community in Lampung, it is known that the resolution of disputes based on indigenous local wisdom is carried out through traditional deliberations or what is called Merwatin. The settlement forum was held to reach consensus among the perpetrators, victims and the community. Dispute resolution mechanisms are initially victims and perpetrators experiencing social sanctions by the community, which is not allowed to mingle with the community before the problems they face are resolved. The next result is known as Pepadun Kamah or Pepadun Kotor, Pepadun Tegitching or Pepadun Miring, and also Pepadun Lukkep or Pepadun terbalik. Sanctions are given among other traditional fines called daw, slaughtering of animals such as buffalo or cow (Albar Diaz Novandi, 2016: i). Deliberative democracy offering teaching of deliberation is the same as the teaching of Pancasila democracy (Five Basic Principles). It is clearly implied in the fourth principle of Pancasila in the legal field belonging to the type of people participation-based responsive law concept (Gumbira, S. W., Handayani, I. G. A. K. R., \& Tedjomurti, K. T. 2019: 199-202).

The tradition that takes place in Ambon is known as local wisdom called pela gandong. Pela gandong is a blood relation and agreement between one country and another, both of which are between land and different islands, also between different ethnicities and religions. This pela gandong relationship has a very important effect on where all people participate in upholding together and maintaining that relationship. Pela gandong implies a kinship relationship despite being of different religions. It can also be interpreted to coexist with tolerance in religious differences so that the current Pela Gandong system still 
plays an important role (Tualeka, Hamzah. 2010: 65). The sense of unity and shared identity is strongly realized and lived with pela renewal ceremonies (pela panas ceremony) that still often take place. The role of the pela gandong has increasingly given space to reconciliation, to be created, in overcoming conflicts between regions that had once separated the two communities but now have managed to reunite. The cultural heritage of the ancestors, namely pela gandong, is proven to be able to connect the ties of friendship that were interrupted in Ambon (Hendry Bakri, 2015: 52-53).

Ironically, when problems occur, governments and law enforcement officials often deny local wisdom and the rules that lives in the community. They chose to prioritize enforcing positive law (state law), even though customary law and local wisdom existed long before the republic was established. Conflict resolution through local wisdom has not been much developed by the government and law enforcement officers because our legal politics are positivism. Quite a lot of local wisdom-based conflict resolution mechanisms in the community. Of course the effectiveness of its effectiveness depends on the obedience of the citizens of the order of the prescription, because outside of it develops a formal legal mechanism based on a state court with the Indonesian Criminal Code and all its legality principles, while the community justice system mechanism is more based on deliberation. The description and illustration above shows that the potential of local wisdom as an alternative solution for resolving violent conflicts can manifest in various scenarios. The challenge lies in how each of us starts to take steps to contribute to the empowerment or creation of the local wisdom stage.

\section{Empowerment of Local Wisdom in The Law Number 7 of 2012 on Social Conflict Resolution}

The diversity of tribes, religions, races, and cultures of Indonesia with a population of more than 260 million people, on one hand, is a nation's wealth that can directly or indirectly contribute positively effort to create the people's welfare. But on the other hand, these conditions can harm national life if there are development disparity, injustice, and socio-economic inequality, as well as unconducive of the dynamics of political life. In addition, the transition democracy increasingly open world order has resulted in rapid social dynamics, including foreign intervention. These conditions placed Indonesia as one of the conflict-prone countries, especially horizontal conflicts. The conflict, have proven resulted in security lapse, the emergence of community fear, environmental damage, property loss, death, and psychological trauma such as revenge, hatred, and antipathy, thus hampering the realization of public welfare.

Based on the above thought, it is necessary to have an umbrella law as a guideline in the resolution of social conflicts, so that the legislators issued The Law No. 7/2012 concerning Social Conflict Resolution. In a general explanation, this law mentioning three important arguments, namely philosophical arguments, sociological arguments, and juridical arguments. The first philosophical 
argument is the guarantee of the continued existence of the ideals of the establishment of the Unitary State of the Republic of Indonesia, realizing the unity and integrity of the nation, without being interrupted due to differences of opinion or conflicts that occur between community groups (Tejomurti, K. 2018: 272). Secondly, the aim of the Unitary State of the Republic of Indonesia is to protect the entire Indonesian nation which consists of diverse ethnic, religious and cultural groups and to protect all of Indonesia's blood spills, including providing guarantees of security and freedom from fear to realize public welfare as mandated in the Indonesian Constitution of 1945. Third, the responsibility of the state to provide protection, promotion, enforcement, and fulfillment of human rights through efforts to create a safe, peaceful, peaceful and prosperous atmosphere both physically and spiritually as a manifestation of the right of every person to protect themselves, family, honor, dignity, and property as well as the right to security and protection from the threat of fear. Freedom from fear is a guarantee of the right to live safely, peacefully, fairly, and prosperously.

Furthermore, the sociological argument for the formation of Law Number 7 of 2012 On Social Conflict Resolution is as follows; First, the Republic of Indonesia, with its diversity of ethnicities, religions, and cultures that is still characterized by disparities in development, injustice, and social, economic and political inequalities, has the potential to create conflict in the community. Secondly, Indonesia, on the one hand, is undergoing a phase of democratic transition and governance, opening up opportunities for the emergence of radicalism movements in the country, and on the other hand, living in an open world order with foreign influence is very vulnerable and has the potential to cause conflict. Third, the increasingly limited wealth of natural resources and environmental carrying capacity can lead to conflict, both of ownership issues and the weaknesses of the management system that do not pay attention to the interests of the local community. Fourth, conflict causes security lapse, the emergence of fear, environment damages and crack of social institutions, property loss, death, psychological trauma (revenge, hate, antipathy), and widening the distance between groups of conflicting parties which is hampering the realization of public welfare. Fifth, conflict management can be carried out comprehensively, integratively, effectively, efficiently, accountably, and transparently as well as on target through dialogical approaches and peaceful methods based on the adequate legal norm. Sixth, in overcoming and resolving the various conflicts, the Indonesian government does not yet have a comprehensive, integrative, effective, efficient, accountable, and transparent conflict management policy format, and also well-targeted based on dialogical approaches and peaceful ways.

Juridical argument for the formation of The Law Number 7 of 2012 concerning Social Conflict Resolution is in the previous period the problem of legislation related to conflict management which is still sectoral and reactive, and not in accordance with the development of the constitutional system. Through analysis of synchronization and harmonization of existing laws and 
regulations, specific laws are needed to regulate social conflict resolution. Article 2 point $\mathrm{j}$ The Law No. 7/2012 concerning Social Conflict Resolution states that conflict resolution reflects the principle of local wisdom. As a principal in the law, local wisdom should become the basis of values and institutions that are put forward in the social conflict resolution that occurs. Unfortunately, the use of local wisdom is not regulated because this law emphasizing on legal formal approaches and the state's official institutions. As is Novri Susan's opinion said that The Law Number 7 of 2012 On Social Conflict Resolution was false in using conflict resolution methods (Novri Susan, 2012: 878). The formal legal approach should be a last resort (ultimum remidium) in handling conflicts. Conflict management which includes conflict prevention, conflict termination, and postconflict recovery activities, at an each stages local wisdom should play a very strategic role.

Furthermore, according to Article 6 paragraph (1) The Law Number 7 of 2012 on Social Conflict Resolution states that conflict prevention is carried out by a. maintaining peaceful conditions in society; b. developing a system for amicable dispute resolution; $\mathrm{c}$. reduce the potential for conflict; and d. build an early warning system. These efforts seem to prioritize the approach from the top down rather than foster awareness based on local wisdom (Novri Susan, 2012: 870). Even though it is not explicitly mentioned in Law Number 7 of 2012 On Social Conflict Resolution, the empowerment of local wisdom in managing conflicts as implied in the law is essentially done through two aspects namely the intrinsic value aspect, and the physical institutional aspect. From the aspect of values, the essence of local wisdom is symbols of harmony and rhythm in life that apply in a society. Values that are believed to be true and become a reference in the daily behavior of local people, as Greertz said that local wisdom is an entity that determines the respect and human dignity in his community (Nurma Ali Ridwan, 2007: 29).

The provisions of Article 6 paragraph (1) are further derivated into Government Regulation Number 2 of 2015 On the Implementation of The Law No. 7/2012 concerning Social Conflict Resolution, which in Article 3 confirms the Central government and Regional governments in accordance with their authority to implement conflict prevention through implementation activities include strengthening local access to wisdom and strengthening social harmony. Strengthening access to local wisdom can be done well when the Regional Government regulates technical implementation through local regulations according to the needs and conditions at the local level (Maria, 2018: 2). Conflict prevention by strengthening access to local wisdom and strengthening social harmony is basically a form of empowerment and utilization of local wisdom values owned by Indonesians who are rich in traditions to maintain harmony and social cohesion which in various regions are known for various diverse and distinctive traditions according to the history and growth of each. However, local wisdom will only become limited to a symbol when it is not maintained and driven by the community. As a normative symbol, perhaps the community still 
memorizes its lessons, but if it is not realized in the daily life these values cannot be manifested in people's lives (Abdul Jamil Wahab, 2014: 222). Local wisdom is the most effective media to prevent, to detect, and to find solutions for conflict resolution. This condition is carried out by inviting people who was involved in the conflict to discuss and to negotiate their desires with other parties. This will give effect to the form of settlement that is considered possible and appropriate, and can be used as conflict early warning system (Herlina Astri, 2011: 158).

From an institutional aspect, The Law Number 7 of 2012 On Social Conflict Resolution regulates that in terminating process of physical violence is an obligation of security forces where controlled by the Indonesian National Police, as stated in Article 13 that (1) Cessation of physical violence as referred to in Article 12 point a is coordinated and controlled by the National Police; (2) Termination of physical violence as referred to in paragraph (1) involves community leaders, religious leaders, and/or traditional leaders; (3) Termination of physical violence as referred to in paragraph (2) is carried out in accordance with the provisions of the legislation. The provisions of Article 13 number (2) only involve informal figures, lacking a meaningful role for them, this seems to emphasize that the security and power approach is more prioritized. The involvement of informal leaders and especially traditional leaders does not seem to be regulated in general and abstract terms; this will eliminate the role of local wisdom in terminating conflict (Maria, 2018: 8).

In the post-conflict recovery stage based on The Law Number 7 of 2012 concerningSocial Conflict Resolution carried out through reconciliation activities; rehabilitation; and reconstruction. In the reconciliation stage based on Article 37 the Central Government and Regional Governments reconcile between the parties by: a. peace negotiations; $b$. granting restitution; and/or forgiveness. The reconciliation as referred to in Article 37 paragraph (1) may be carried out with Customary Institutions and/ or Social Institutions or Special Task Force for Social Conflict Resolution. In line with Article 37, Article 40 the Law Number 7 of 2012 On Social Conflict Resolution emphasizes that conflict resolution institutions consist of the Central Government, Regional Governments, Customary Institutions and/or Social Institutions, and the Social Conflict Resolution Task Force. Conflict resolution institutions in the form of Customary Institutions and / or Social Regulations are more emphasized in Article 41 The Law Number 7 of 2012 On Social Conflict Resolution states: (1) Conflict resolution is carried out by the Government and Regional Governments by prioritizing existing Customary Institutions and/or Social Institutions and their existence is recognized; (2) The Government and Regional Governments recognize the results of the resolution of the Conflict through the mechanism of Customary Institutions and / or Social Regulations; (3) The results of the agreement on the resolution of the conflict through the mechanism of Customary Institutions and/or Social Institutions as referred to in paragraph (1) have binding power for the community groups who is involved in the conflict; (4) In the case of conflict resolution through the mechanism of Customary Institutions and/ or Social Institutions as referred to in 
paragraph (1) cannot be resolved, the conflict resolution shall be carried out by the Special Task Force for Social Conflict Resolution; (5) Settlement of conflicts through the mechanism of Customary Institutions and/or Social Institutions as referred to in paragraph (1) shall be facilitated by the Regional Government by involving local sub-district and village officials..

The application of Customary Institutions and/or Social Institutions then is explained through Government Regulation Number 2 of 2015 On The Law Number 7 of 2012 On Social Conflict Resolution, which in Article 7 states that (1) The Government and regional government in carrying out conflict prevention, optimizing the peaceful settlement of disputes through deliberations of consensus; (2) The peaceful settlement of disputes as referred to in paragraph (1) may involve the participation of the community; (3) The community as referred to in paragraph (2) includes (a) religious leaders, (b) traditional leaders, and/ or (c) other elements of the community including customary institutions and/ or social institutions; and (4) The peaceful of disputes settlement as referred to in paragraph (1) shall be carried out concerning religious norms, moral norms, customary norms, and statutory provisions.

Customary institutions and/or Social Institutions referred to in the two regulations above are essentially the utilization and actualization of local wisdom-based institutions which is owned by the community. Historically, every community has lived and developed non-formal institutions, albeit with the unique names or specific names of their respective regions, which perform the function for preventing and resolving social conflicts based on local wisdom by prioritizing harmony approaching and peace (Althien John Pesurnay, 2018: 4)

In fact, local wisdom-based institutions are often considered less important because the central and regional governments tend to prioritize formal approaches and power in resolving social conflicts, although it does not rule out the exclusion of local wisdom because of the economic and political interests of the authorities. During this time, local wisdom lies with the development interests that are centralistic and top-down (Nurma Ali Ridwan, 2007: 31). In the midst of globalization and current technological advances, it is a suitable moment to explore and actualize more values and institutions of local wisdom as an instrument to encourage regional development and to strengthen social cohesion that is needed for resolving social problems with dignity.

\section{Conclusion}

1. The potential for social conflict in Indonesia is quite high, remembering the diversity of ethnicity, religions, races, and cultures in addition to the large enough population. On the other hand, Indonesia also has a treasure of values and institutions of local wisdom that can be empowered and revitalized so that they can function more as guardians of harmony and rhythm in people's lives for preventing conflicts. 
2. The diversity of local wisdom forms that are empirically live generations by generation and owned by each community at the local level is the social asset that can be empowered in the social conflict resolution. Local wisdom has two important roles, namely in preventing social conflict and at the same time providing solutions related to the resolution of social conflicts that have occurred.

3. The Law No. 7/2012 concerning Social Conflict Resolution using the principle of local wisdom, it should empower the principle of local wisdom in its implementation. Empowerment is done by actualizing values and institutionalizing local wisdom in social conflict resolution, namely in the stages of conflict prevention, termination of conflict and post-conflict recovery.

\section{Recommendation}

1. The central government through the Ministry of Social Affairs, the Ministry of Education and Culture and other related institutions should increase conflict prevention efforts through organizing activities to strengthen access to local wisdom and strengthen social harmony through various media such as arts, culture, and other creative social activities. On the other hand, the central and regional governments responsible for social conflict resolution should prioritize the utilization of local wisdom values and institutions in social conflict resolution rather than promoting an approach based on authority and normativity based on state law.

2. Local government should be able to strengthen the existence and role of local wisdom in the context of preventing social conflicts by preparing Regional Regulations (Perda) according to their respective needs and conditions. Strengthening local wisdom can be done through formal and informal education.

\section{BIBLIOGRAPHY:}

\section{Book:}

Abdul Jamil Wahab. (2014) Manajemen Konflik Keagamaan (Analisis Latar Belakang Konflik Keagamaan Aktual. Jakarta : PT Elex Media Komputindo.

Abdur Rozaki. (2010) "Resolusi Konflik Berbasis Kearifan Lokal”. Laporan Penelitian. Yogyakarta : IRE.

Ade Saptomo. (2010). Hukum dan Kearifan Lokal Revitalisasi Hukum Adat Nusantara. Jakarta : PT. Grasindo.

Albar Diaz Novandi. (2016). “Analisis Penyelesaian Tindak Pidana Berbasis Kearifan Lokal Adat Lampung (Studi Kasus Di Kecamatan Bandar Mataram Kabupaten Lampung Tengah)". Skripsi. Bandar Lampung : Fakultas Hukum Universitas Lampung. 
Ayatrohaedi. (1986). Kepribadian Budaya Bangsa (Local Genius). Jakarta : Pustaka Jaya.

Amien, M.A. (2005). Kemandirian Lokal: Konsepsi Pembangunan, Organisasi, dan Pendidikan dari Perspektif Sains Baru. Jakarta: Gramedia.

Bernadus Steni. (2009). Hukum Yang Bergerak Tinjauan Antropologi Hukum. Jakarta : Yayasan Obor Indonesia.

Colletta, N.J. dan M.L. Cullen. (2000). Violent Conflict and the Transformation of Social Capital. Washington D.C. : The World Bank.

Fukuyama, F. (2002). The Great Disruption: Hakikat Manusia dan Rekonsruksi Tatanan Sosial. Yogyakarta: Qalam Press.

Field, J. (2010). Modal Sosial (Terjemahan). Bantul: Kreasi Wacana.

Jawahir Tontowi. (2007). Hukum, Kekerasan dan Kearifan Lokal, Penyelesaian Sengketa di Sulawesi Selatan. Jogyakarta : Pustaka Fahima.

James P. Spradley and David W. McCurdy. (1987).Conformity and Conflict, Reading in Cultural Antropogy. Little Brown and Company.

Karrie McLaughlin dan Ari Perdana. (2010). Conflict and Dispute Resolution in Indonesia, Information from the 2006 Governance and Decentralization Survey. Jakarta : World Bank.

Koentjaraningrat. (1993). Manusia dan Kebudayaan di Indonesia. Jakarta : Penerbit Djambatan.

Lyotard, J.F. (2009). Kondisi Postmodernisme: Suatu Laporan untuk Pengetahuan (Terjemahan). Yogyakarta: Selasar Publishing.

McNeely, I.F. dan L. Wolverton. (2010). Para Penjaga Ilmu dari Alexandria Sampai Internet. Jakarta: Literari.

Nasikun. (1995). Sistem Sosial Indonesia. Jakarta : Rajawali Pers.

Tualeka Hamzah. (2010). “Konflik dan Integrasi Sosial Bernuansa Agama, Studi tentang Pola Penyelesaian Konflik dalam Persfektif Masyarakat". Disertasi. Surabaya: Program Pascasarjana IAIN Sunan Ampel.

\section{Journal:}

Bali Pos, Senin, 06 Oktober 2011.

Chastiti Mediafira Wulolo dan Semuel Renmaur. (2019). "Meredam Konflik dalam Pusaran Siber dalam Proses Penetapan Hasil Rekapitulasi Pemilu Serentak". Jurnal Penelitian Politik, LIPI, 2019. Vol. 16, No. 2. Desember 2019.

David Bennet's, (2017). “The Currency of Desire: Libidinal Economy, Psychoanalysis, and Sexual Revolution", Journal of Cultural Economy, Volume 10, 2017 - Issue 5.

Davide Cadeddu, (2019). "State, Nationalism and Globalization", Journal of Culture, Politics and Innovation, 2019, Issue 2.

18 Yustisia Volume 9 Number 1 (January-April 2020) $\quad$ Social Conflict Resolution through ... 
Deny Hidayati. (2016). “Memudarnya Nilai Kearifan Lokal Masyarakat dalam Pengelolaan Sumber Daya Air”, Jurnal Kependudukan Indonesia, Vol. 11, No. 1 Juni 2016.

Gumbira, S. W., Handayani, I. G. A. K. R., \& Tedjomurti, K. T. (2019). The Urgency of Presidential Policy to Revitalize and Maintain the Existence of Cooperatives Based on Pancasila. Sriwijaya Law Review, 3(2), 199-224.

Hendry Bakri, “Resolusi Konflik melalui Pendekatan Kearifan Lokal Pela Gandong di Kota Ambon", The Politics: Jurnal Magister Ilmu Politik Universitas Hasanuddin, Volume 1, Number 1, January 2015.

Herlina Astri. (2011). Penyelesaian Konflik Sosial Melalui Penguatan Kearifan Lokal. Pusat Pengkajian, Pengelolaan Data dan Informasi Sekretariat Jenderal DPR-RI: Jurnal Aspirasi, Vol. 2, No. 2, Desember 2011.

I Nyoman Nurjaya. (2005). “Reorientasi Tujuan dan peranan Undang-Undang dalam Masyarakat Multi Budaya : Perspektif Antropologi Undang-Undang”. University Kebangsaan Malaysia : Jurnal Undang-Undang dan Masyarakat Malaysian Journal of Law and Society, Jilid 1, Volume 9, 2005.

I Putu Gelgel. (2011). "Peradilan Adat (Agama) Sebagai Resolusi Konflik". Bali Pos, Senin, 06 Oktober 2011.

Made Sudjana. (2010). "Menghidupkan Lembaga Peradilan Adat Bali". Koran TOKOH Senin, 20 Desember 2010.

Moch Nurhasim et.al. (2016). "Konflik Dalam Pilkada langsung”. Jurnal Penelitian Politik. LIPI. 2016. Vol. 10, No. 2. Desember 2016.

Novri Susan. (2012). "Scenario Building on Law No. 7 of 2012 about social conflict intervention: The possible future of land conflict management in Indonesia". The $3^{\text {rd }}$ International Conference on Sustainable Future for Human Security SUSTAIN 2012. Procedia Environmental Sciences 17 (2013) 870. Published by Elsevier B.V.

Nurma Ali Ridwan. (2007) "Landasan Keilmuan Kearifan Lokal". P3M STAIN Purwokerto: Jurnal Studi Islam dan Budaya Ibda`. Vol. 5, No. 1, Jan-Jun 2007.

Tejomurti, K. (2018). Memberdayakan Koperasi Sampah Berbasis Otonomi Desa dalam Mewujudkan Desa Ramah Lingkungan dan Berkelanjutan. Law Review, 17(3), 272296.

\section{Website:}

Althien John Pesurnay. (2018) “Local Wisdom in a New Paradigm: Applying System Theory to the Study of Local Culture in Indonesia". https://iopscience.iop.org/ article/10.1088/1755-1315/175/1/012037, diakses 28 Pebruari 2020.

Darmawan Salman. (2011) “Dapatkah Kearifan Lokal Fungsional Dalam Pengelolaan Konflik Ditengah Preskripsi Global?" Makalah, Jurusan Sosial Ekonomi Pertanian Fakultas Pertanian Universitas Hasanuddin : Makasar, 2011. http://alwyrachman. blogspot.com/2011/04/dapatkah-kearifan-lokal-fungsional.html, accesed on 11 Maret 2012. 
Maria. (2018) "Local wisdom of indigenous society in managing their customary land: a comparative study on tribes in Indonesia". https://doi.org/10.1051/ e3sconf/20185200023, accesed on 28 Pebruari 2020.

https://www.wartaekonomi.co.id/read173350/jk-ketidakadilan-sumber-utamakonflik.html, diakses 9 Januari 2020.

https//www.kemsos.go.id, accesed on 27 Februari 2019.

(https:/ / www.seputarpengetahuan.co.id/2017/10/ pengertian-kearifan-lokalmenurut-para-ahli-ciri-ciri-ruang-lingkup-contoh.html, accesed on 26 Februari 2020). 